\title{
Intercropping of Several Cultivars of Banana and Plantain under Coconut Based in North Sulawesi, Indonesia
}

\author{
Ibrahim Erik Malia ${ }^{1, *}$ and Yusuf ${ }^{2}$ \\ ${ }^{1}$ Assessment Institute for Agricultural Technology at North Sulawesi, Indonesia Ministry of \\ Agriculture, PO box 1345, Manado Indonesia 95013 Telp/WA: 062-85256382302. E-mail: \\ ${ }^{2}$ Indonesian Center for Horticulture Research and Development. J1. Tentara Pelajar No.3C Bogor, \\ West Java, Indonesia 16111.
}

\begin{abstract}
The Research has been conducted in Pandu Experimental Garden, Talawaan Bantik Village, North Sulawesi, titled "Intercropping of Several Cultivars of Banana and Plantain under Coconut Based in North Sulawesi, Indonesia". The aims of the research were to study suitability of several banana and plantain intercropped into coconut based farming system. The materials and methods used were monoculture coconut plantation, hybrid Khina-1 planted in 1986, designed in RCBD, 5 treatments were the banana and plantain cultivars Mas, Gapi, Gepok Tanjung, Goroho and Raja. Then the Least Significant Difference Test (LSD) was used for mean separations. Significantly, was determined at the $p=0.05$ probability level. In this experiment also, using t-test to compare the effect of natural shade of the coconut canopy with an open field for the five varieties tested. Then, using 20 plants for each variety and treatment, served as replication. Two dwarf cultivars, Mas (banana) and Goroho (plantain) indicated the significant vegetative and generative growth shorter than the three tall cultivars, Gapi, Gepok Tanjung and Raja. It is also concluded that coconut based using Hybrid Khina-1 varieties, spacing $8 \mathrm{~m} \times 8 \mathrm{~m}$ square system is suitable for intercropping with banana and plantain, especially the Dwarf Mas and Goroho.
\end{abstract}

\section{Introduction}

Coconut plantations have valuable land for other purposes, such as for intercropping system implementation. On the other hand, in Indonesia most coconut lands are cultivated in monoculture system or unarranged mix cropping system. This farming practice results low productivity referring to farmer income as well as their welfare. Since the farmer has only an average of 1 ha where the annual productivity of copra is only $1.1 \mathrm{t} \mathrm{ha}^{-1}$, their income is very low. For example, in North Sulawesi, the main coconut production center in Indonesia, the price of copra in 2019 is average IDR 5,500,000 $\mathrm{t}^{-1}$ (U\$ $1=$ IDR 13,200), meaning the farmer's income is only about IDR 6,050,000. If the farmer only has the job, they are recorded as the poor or live under poverty line, less then U\$ 1.9 a day [1]. This problems

*Corresponding author: erikmalia08@gmail.com 
bring about many farmers sell their lands or convert it into other uses.

There are many opportunities to solve the problem of in efficiency of coconut cultivation, such as optimizing the land with intercropping. There are several economic commodities suitable for intercropping in coconut land. Rationally, monoculture of coconut plantation can't guarantee the prosperous farmers [2]. In Indonesia, most coconut land $(97 \%)$ are cultivated in monoculture [3]. Although, it is managed in high density, monoculture practices is not profitable. On the other hand, the monoculture coconut is believed that there are very much opportunities to optimize such a intercropping purpose. For example, coconut monoculture only produce 100 nut a year, it is only 17.1 ton/ha or $6.1 \%$ of the maximum biomass production potency [4].

The light transmission trough the canopy varies follows plant age and almost it is contrary with the covering of canopy [5]. Furthermore, it is recorded that the highest coconut canopy coverage was in 8-30 years age, in conventional spacing $9 \mathrm{~m} \times 9 \mathrm{~m}$ triangular pattern, the canopy coverage is only $60 \%$, then, over 30 years, the coverage could be only $20 \%$ [4] Another research conducted in Indonesia, recorded that based on the calculation of plant density $100-200$ /ha, the effective area used is only $12.57-25.14 \%$, therefore, the rest effective land is $87.43-74.86 \%$ [6]. It is reported also that $86 \%$ of coconut root was only be found in $30-130 \mathrm{~cm}$ in depth [7]. Therefore, the land maximum effectively used is only at radius $2 \mathrm{~m}[8]$.

For effectiveness of intercropping it is necessary to consider the kind of intercrops in developing coconut-based farming system tolerant for environmental limitation especially light. For, example, banana. Light has influence on the growth and yield of banana. On the other hand, there are many reasons considered that banana is still possible to use as intercrops within coconut based farming system, such as the light transmission to the grown still possible for certain varieties like dwarf banana. Banana widely popular and important food usually cultivated in intercropping system around the world, for example, in Ghana $99 \%$ of young coconut were intercropped with food crops, mainly [9], while in the Philippines, 60 to $70 \%$ of estimated 3.1 million hectares of coconut is intercropped with recommended crops including banana [8].In Kenya, plantain or banana intercropped are reported to be one of the most profitable coconut intercrops [7]. Meanwhile, in North Sulawesi, the most important coconut production in Indonesia, banana and plantain is commonly planted

Bananas originate from South East Asia $[10,11]$. Since the banana is a tropical plant, it requires warm temperatures and an adequate supply of water. Although sensitivity to photoperiod has been noted in certain cultivars [12], banana is an almost non-seasonal crop that reliably provides a carbohydrate source year-round which makes it vitally important to both nutrition and food security. Plantain is considered an excellent source of energy and nutrients: it is estimated that $100 \mathrm{~g}$ of the edible part of raw plantain provides $122 \mathrm{kcal}$, contains $1.30 \mathrm{~g}$ of protein, $0.37 \mathrm{~g}$ of fat, $0.6 \mathrm{mg}$ of iron, $0.14 \mathrm{mg}$ of zinc and $457 \mu \mathrm{g}$ of $\beta$ carotene [13]. Iron and zinc deficiencies are commonly reported in children and women of reproductive age in many developing countries $[14,15,6]$. Iron deficiency is the prevailing nutritional deficiency in the world and is the main cause of anemia [11].

In order to solve the problems mentioned above and to optimize the coconut-based farming system by using coconut and plantain intercropped in North Sulawesi. Therefore, this research was conducted aimed to study suitability of several banana and plantain intercropped into coconut based farming system.

\section{Materials and Methods}

The research was carried out during two years (2014-2016) in Pandu Experimental Garden, North Sulawesi, Indonesia using coconut based planted in 1986. The coconut variety used 
was Khina-1, a hybrid crossed by Tenga Tall Variety and Nias Dwarf Variety, both was local Indonesian varieties.

In this experiment five banana and plantain cultivars were tested intercropped into the coconut-based plantation conducted by using a complete randomized block design with three replications. The treatments were the banana and plantain cultivars: $\mathrm{A}=\mathrm{Mas}, \mathrm{B}=\mathrm{Gapi}$, $\mathrm{C}=$ Gepok Tanjung, $\mathrm{D}=$ Goroho and $\mathrm{E}=$ Raja. Then the Least Significant Difference Test (LSD) was used for mean separations. Significantly, was determined at the $p=0.05$ probability level.

In this experiment also, using t-test to compare the effect of natural shade of the coconut canopy with an open field for the five varieties tested. Then, using 20 plants for each variety and treatment, served as replication.

The planting materials of banana used sword suckers having two leaves, whereas, it is different weight and height among the cultivars. The suckers of Dwaft Mas Cultivar and Goroho average $60 \mathrm{~cm}$ in height, while the tall cultivars, Gapi, Gepok Tanjung and Raja average $85 \mathrm{~cm}$ in height. The banana and plantain was cultivated in a row between two coconut rows, $3 \mathrm{~m}$ spacing in row. The suckers planted in $40 \mathrm{~m}$ x $40 \mathrm{~m}$ x $40 \mathrm{~m}$ holes prepared before. The banana and plantain was fertilized conventionally, 4 times a year. First, in 1 month after planting $150 \mathrm{~g}$ Urea $(45 \% \mathrm{~N}), 400 \mathrm{~g} \mathrm{SP}-36\left(36 \% \mathrm{P}_{2} \mathrm{O}_{5}\right), 200 \mathrm{~kg} \mathrm{KCl}$ $\left(60 \% \mathrm{~K}_{2} \mathrm{O}\right)$. Then, in the next, every 3 months was applied $150 \mathrm{~g} \mathrm{Urea}$, and $100 \mathrm{~g} \mathrm{KCl}$.

The parameters measured were (1) number of ratoon in certain age, 3, 6, 9 and 12 months after planting (map); (2) number of leaves in certain age, 3, 6, and 9 map; (3) Plant height at inflorescence of main crop, I ratoon and II ratoon; (4) Plant girth at inflorescence of main crop, I ratoon and II ratoon; (5) Number of hands/bunch of main crop, I ratoon and II ratoon; (6) days of flowering of main crop, I ratoon and II ratoon; (7) Days of harvesting of main crop, I ratoon and II ratoon; (8) Average hand weight of main crop, I ratoon and II ratoon; and (9) Number of fingers/hand.

\section{Results and Discussion}

The result shown in Table 1 , determine that there were significant differences in the parameter of number of ratoon in certain age of several banana and plantain intercropped into coconut based in Talawaan Bantik, North Sulawesi. In the 3 months old, when the plants just in rapid juvenile growing, except between Gapi and Raja Cultivars, all cultivars were significantly different. However, the higher number of ratoon found in Mas Cultivar (5.5 ratoon), followed by Goroho, Raja, Gapi, and Gepok Tanjung, respectively. In 6 months old, the dwarf cultivars, Mas (9.25 ratoon) and Goroho (6.50 ratoon) shown the higher number of ratoon than other cultivars. In fact, Mas and Goroho are two kind of banana and plantain classified into fast grow cultivars. These seem that in the next level of age, 9 months and 12 month the production of ratoon pattern became similar. In the 12 months, when the generative of the first ratoon, the number of ratoon produced research $15.50 ; 13.75 ; 10.50 ; 9.75$ and 9.75, respectively for Mas, Goroho, Gapi, Gepok Tanjung and Raja. In farmer practices, the excessive ratoon is usually catting or thinning. The thinning remain 2 or 3 ratoon in fruiting phase. It is important to be conducted in banana cultivation because the needs to produce well bunches. In addition, banana and plantain are easy to produce, implying their plantations and production can be beneficial in association with other crops in various environments including home gardens. However, a main handicap for these crops' production remains the quality of suckers [16, 17]. 
Tabel 1. Number of Ratoon in Certain Age of Bananas and Plantains under Coconut in Talawaan Bantik Village, North Sulawesi, 2015-2016.

\begin{tabular}{|l|r|r|r|r|}
\hline Cultivars & $\begin{array}{r}\text { No. of Ratoon } \\
\text { (3 month) }\end{array}$ & $\begin{array}{r}\text { No. of Ratoon } \\
\text { (6 month) }\end{array}$ & $\begin{array}{r}\text { No. of Ratoon } \\
\text { (9 month) }\end{array}$ & $\begin{array}{r}\text { No. of Ratoon } \\
\text { (12 month) }\end{array}$ \\
\hline Mas & $5.50 \mathrm{~d}$ & $9.25 \mathrm{c}$ & $12.50 \mathrm{c}$ & $15.50 \mathrm{c}$ \\
\hline Gapi & $1.25 \mathrm{~b}$ & $4.25 \mathrm{a}$ & $8.50 \mathrm{~b}$ & $10.50 \mathrm{a}$ \\
\hline Gepok Tanjung & $0.25 \mathrm{a}$ & $4.25 \mathrm{a}$ & $6.75 \mathrm{a}$ & $9.75 \mathrm{a}$ \\
\hline Goroho & $2.75 \mathrm{c}$ & $6.50 \mathrm{~b}$ & $8.75 \mathrm{~b}$ & $13.75 \mathrm{~b}$ \\
\hline Raja & $1.75 \mathrm{~b}$ & $4.50 \mathrm{a}$ & $8.00 \mathrm{~b}$ & $9.75 \mathrm{a}$ \\
\hline
\end{tabular}

Notes: The numbers followed by the same letter in the same column are not significantly different in $5 \%$ LSD test.

In this experiment, the number of leaves were not different significantly in mature crops, this only different in earlier, 3 months where Gepok Tanjung, Gapi and Raja seem to grow lower than the Dwarf Mas and Goroho (Table 2). The number of leaves is important to maintain banana itself. The energy used further in plant growth produce in leaves by photosynthetic process [18]. According to [8], that only the heaviest shade affected banana vegetative growth. When the density of a commercial banana plantation is high and light transmitted to the understory is reduced to $10 \%$ of the above canopy intensity, growth and production of the plants are severely affected [10]. That the reason why in general cultivation, arrangement of spacing, cutting off the old leaves is always prioritized.

Tabel 2. Number of Leaves in Certain Age of Bananas and Plantains under Coconut in Talawaan Bantik Village, North Sulawesi, 2015-2016.

\begin{tabular}{|l|r|r|r|}
\hline Cultivars & $\begin{array}{r}\text { Number of Leaves at } \\
\text { 3 Months }\end{array}$ & $\begin{array}{r}\text { Number of Leaves at } \\
\text { 6 Months }\end{array}$ & $\begin{array}{r}\text { Number of Leaves at } \\
\text { 9 Months }\end{array}$ \\
\hline Mas & $5.25 \mathrm{~b}$ & $5.75 \mathrm{a}$ & $5.75 \mathrm{a}$ \\
\hline Gapi & $3.50 \mathrm{a}$ & $5.25 \mathrm{ab}$ & $6.75 \mathrm{a}$ \\
\hline Gepok Tanjung & $3.25 \mathrm{a}$ & $4.75 \mathrm{~b}$ & $6.50 \mathrm{a}$ \\
\hline Goroho & $4.50 \mathrm{~b}$ & $6.25 \mathrm{a}$ & $6.25 \mathrm{a}$ \\
\hline Raja & $3.75 \mathrm{a}$ & $5.25 \mathrm{ab}$ & $6.00 \mathrm{a}$ \\
\hline
\end{tabular}

Notes: The numbers followed by the same letter in the same column are not significantly different in $5 \%$ LSD test.

The plant height and plant girth measured at inflorescence emerging shown similar pattern where that the Dwarf Mas and Goroho was shorter than other Tall cultivars (Table $3)$. Moreover, Mas $(181.34 \mathrm{~cm})$ was significantly shorter than Goroho $(223.33 \mathrm{~cm})$, then Goroho very significantly different with the 3 tall cultivars, Raja $(346.83 \mathrm{~cm})$, Gapi $(352.65$ $\mathrm{cm})$ and Gepok Tanjung $(392 \mathrm{~cm})$. On the other hand, among the three tall cultivars, Gapi and Raja have height and girth not significant different on all stage, where the Gepok Tanjung was different with the two other tall cultivars.

Tabel 3. Plant height and plant girth at inflorescence emerging of 5 varieties under coconut in Talawaan Bantik Village, North Sulawesi, 2015-2016.

\begin{tabular}{|l|c|c|c|c|c|c|}
\hline Cultivars & \multicolumn{3}{|c|}{ Plant height at inflorescence (cm) } & \multicolumn{3}{c|}{ Plant girth at inflorescence (cm) } \\
\hline & Main crop & I ratoon & II ratoon & $\begin{array}{c}\text { Main } \\
\text { crop }\end{array}$ & I ratoon & II ratoon \\
\hline Mas & $181.34 \mathrm{a}$ & $193.37 \mathrm{a}$ & $193.69 \mathrm{a}$ & $38.23 \mathrm{a}$ & $36.89 \mathrm{a}$ & $38.89 \mathrm{a}$ \\
\hline Gapi & $352.65 \mathrm{c}$ & $344.84 \mathrm{c}$ & $350.54 \mathrm{c}$ & $60.28 \mathrm{c}$ & $62.19 \mathrm{c}$ & $63.37 \mathrm{c}$ \\
\hline Gepok Tanjung & $392.58 \mathrm{~d}$ & $421.56 \mathrm{~d}$ & $423.23 \mathrm{~d}$ & $92.40 \mathrm{~d}$ & $100.30 \mathrm{~d}$ & $103.24 \mathrm{~d}$ \\
\hline Goroho & $223.33 \mathrm{~b}$ & $223.35 \mathrm{~b}$ & $227.11 \mathrm{~b}$ & $42.70 \mathrm{~b}$ & $45.45 \mathrm{~b}$ & $43.56 \mathrm{~b}$ \\
\hline Raja & $346.83 \mathrm{c}$ & $356.22 \mathrm{c}$ & $355.01 \mathrm{c}$ & $62.38 \mathrm{c}$ & $64.80 \mathrm{c}$ & $66.40 \mathrm{c}$ \\
\hline
\end{tabular}

Notes: The numbers followed by the same letter in the same column are not significantly different in $5 \%$ LSD test. 
It was surprised where the Dwarf Mas (banana) and Dwarf Goroho (plantain) got flowering very early. Mas flowered in 191 dap and Goroho 223.33 dap. These much earlier than the dwarf cultivars identified in India, Grand Naine took 280 days to flower and 386 days for harvest of main crop [19] and Dwarf Cavendish took 275 days to flower [20]. The days of harvesting also have shown that the dwarfs were harvesting earlier that that in India $[19,21,22]$. Meanwhile, the tall varieties Gapi and Raja flowering were not significantly different. Gapi flowered in 302.75 dap where Raja flowered in 316.83 dap. On the other hand, they were different compared with Gepok Tanjung Cultivar having 382.58 dap to flower for the main crop.

In General, in lowland Indonesia days of banana harvesting around 85-100 after flower emerged, while in highland took 98-115 days after flower [23]. In this experiment was found that the Dwarf Mas 60.25 days and Goroho 53.67 days after flowering. Goroho harvested earlier due to it plantain character where the fruit have to be harvested before ripping. The fruit harvesting when it is suitable to consume. Moreover, the experimental results shown that Mas and Goroho, two cultivars of banana and plantain expressed as extreme dwarf. They were about 25-28 days ripe earlier than general banana or plantain. In the contrary, the tall cultivars recorded that Raja was ripe 84.92 days after flowering, followed by Gapi ripe 87 days after flowering and the longest was Gepok Tanjung 99.92 days after flowering

Tabel 4. Days of Flowering and Days of Harvesting of 5 varieties under coconut in Talawaan Bantik Village, North Sulawesi, 2015-2016.

\begin{tabular}{|l|l|l|l|l|l|l|}
\hline \multirow{2}{*}{ Cultivars } & \multicolumn{2}{|l|}{ Days of flowering } & \multicolumn{2}{l|}{ Days of harvesting } & \\
\cline { 2 - 7 } & $\begin{array}{l}\text { Main } \\
\text { crop }\end{array}$ & I ratoon & II ratoon & Main crop & I ratoon & II ratoon \\
\hline Mas & $191.00 \mathrm{a}$ & $203.25 \mathrm{a}$ & $201.75 \mathrm{a}$ & $251.25 \mathrm{a}$ & $259.00 \mathrm{a}$ & $250.25 \mathrm{a}$ \\
\hline Gapi & $302.75 \mathrm{c}$ & $304.75 \mathrm{c}$ & $300.50 \mathrm{c}$ & $389.75 \mathrm{c}$ & $379.25 \mathrm{c}$ & $385.50 \mathrm{c}$ \\
\hline $\begin{array}{l}\text { Gepok } \\
\text { Tanjung }\end{array}$ & $382.58 \mathrm{~d}$ & $361.50 \mathrm{~d}$ & $363.25 \mathrm{~d}$ & $482.50 \mathrm{e}$ & $455.50 \mathrm{~d}$ & $462.00 \mathrm{e}$ \\
\hline Goroho & $223.33 \mathrm{~b}$ & $223.25 \mathrm{~b}$ & $227.00 \mathrm{~b}$ & $277.00 \mathrm{~b}$ & $278.25 \mathrm{~b}$ & $282.00 \mathrm{~b}$ \\
\hline Raja & $316.83 \mathrm{c}$ & $326.22 \mathrm{~d}$ & $325.01 \mathrm{~d}$ & $401.75 \mathrm{~d}$ & $412.75 \mathrm{~d}$ & $411.75 \mathrm{~d}$ \\
\hline
\end{tabular}

Notes: The numbers followed by the same letter in the same column are not significantly different in $5 \%$ LSD test.

Tabel 5. Bunch characters and yield of the five varieties under coconut, North Sulawesi, 2008-2009

\begin{tabular}{|l|l|l|l|l|l|c|c|c|c|}
\hline \multirow{3}{*}{ Cultivars } & \multicolumn{3}{|l|}{ No. of hands/bunch } & \multicolumn{3}{l|}{ No.of fingers/hand } & \multicolumn{3}{|c|}{$\begin{array}{c}\text { Average Hand weight } \\
\text { (g) }\end{array}$} \\
\cline { 2 - 10 } & $\begin{array}{l}\text { Main } \\
\text { Crop }\end{array}$ & $\begin{array}{l}\text { I } \\
\text { ratoon }\end{array}$ & $\begin{array}{c}\text { II } \\
\text { Ratoon }\end{array}$ & $\begin{array}{l}\text { Main } \\
\text { crop }\end{array}$ & $\begin{array}{c}\text { I } \\
\text { ratoon }\end{array}$ & $\begin{array}{c}\text { II } \\
\text { ratoon }\end{array}$ & $\begin{array}{c}\text { Main } \\
\text { crop }\end{array}$ & I ratoon & $\begin{array}{c}\text { II } \\
\text { ratoon }\end{array}$ \\
\hline Mas & $8.00 \mathrm{~b}$ & $8.25 \mathrm{~b}$ & $8.75 \mathrm{~b}$ & $15.25 \mathrm{a}$ & $15.00 \mathrm{a}$ & $15.25 \mathrm{a}$ & $867 \mathrm{a}$ & $712 \mathrm{a}$ & $723 \mathrm{a}$ \\
\hline Gapi & $8.25 \mathrm{~b}$ & $8.00 \mathrm{~b}$ & $9.00 \mathrm{~b}$ & $14.50 \mathrm{a}$ & $15.00 \mathrm{a}$ & $15.25 \mathrm{a}$ & $1497 \mathrm{c}$ & $1423 \mathrm{~b}$ & $1472 \mathrm{c}$ \\
\hline $\begin{array}{l}\text { Gepok } \\
\text { Tan. }\end{array}$ & $16.50 \mathrm{c}$ & $\begin{array}{l}16.25 \\
\mathrm{c}\end{array}$ & $18.00 \mathrm{c}$ & $17.75 \mathrm{c}$ & $18.25 \mathrm{~b}$ & $18.00 \mathrm{~b}$ & $1778 \mathrm{c}$ & $1623 \mathrm{c}$ & $1633 \mathrm{c}$ \\
\hline Goroho & $5.75 \mathrm{a}$ & $6.00 \mathrm{a}$ & $5.75 \mathrm{a}$ & $15.00 \mathrm{a}$ & $15.25 \mathrm{a}$ & $15.25 \mathrm{a}$ & $1224 \mathrm{~b}$ & $1230 \mathrm{~b}$ & $1247 \mathrm{~b}$ \\
\hline Raja & $8.75 \mathrm{~b}$ & $8.75 \mathrm{~b}$ & $9.00 \mathrm{~b}$ & $16.25 \mathrm{~b}$ & $16.50 \mathrm{a}$ & $16.00 \mathrm{a}$ & $1465 \mathrm{c}$ & $1482 \mathrm{bc}$ & $1482 \mathrm{c}$ \\
\hline
\end{tabular}

Notes: The numbers followed by the same letter in the same column are not significantly different in $5 \%$ LSD test.

The tall cultivar Gepok Tanjung recorded as the highest in number of hands/bunch (16.5) followed by other tall cultivar Raja (8.75) and Gapi (8.00), while the dwarfs were lower, Mas (8.00) and Goroho (5.75). The high hands/bunch of Gepok Tanjung due to its bundles, all the female flower was developed to be fingers despite of they became smaller 
in tips of the bunch. Then, like in parameter number of hands/bunches, Gepok Tanjung also recorded as the hinges in number of fingers/hand (17.75), it was significantly different with other cultivars, followed by Raja (16.5) different to other cultivars. Then, the rest tall cultivar Gapi and the two dwarf cultivars were not significantly different in fingers/hand parameter.

\subsection{Comparison of the Natural Shade of Coconut Canopy and Open Field for Banana and Plantain Growth and Production}

The effects of natural shade under coconut plantation of banana and plantain growth and production are shown in Table 6 . The effect on vegetative characters determined are number of ratton in 3 stages (3, 9 and 15 months age), number of leaves also in 3 stages (3.6 and 9 months age), plant height, and plant girth in inflorescence; while the generative characters are days of flowering, days of harvesting, number of hand/bunch, average hand weight and number of fingers/hand. Based on the observation on the 5 varieties both in vegetative and generative characters, then they were classified into two groups, namely dwarf and tall varieties. There are two dwarf varieties, such as, Mas and Goroho; while the rest three varieties are Gapi, Gepok Tanjung and Raja.

\subsection{Dwarf Varieties}

The results showed that the dwarf varieties were more adaptive against coconut canopy shade than the tall varieties both in vegetative and generative characters. Mas variety was only different in plant height. It is natural, shading produced taller plants due to shoot growth as they look for light, indicating the activation of some phototropism responses [18, $24,25]$. It was also stated by other researchers that plant grown under low light levels have shown more epical dominance than those grown in high light environment resulting in taller plants under shade [26]. It is also possible that the dwarf varieties have ability to continue photosynthesis at light deficit conditions [4]. Meanwhile, on other characters shown there were no significantly different, meaning that the shade of coconut (Khina-1 varieties) spacing $8 \mathrm{~m} \times 8 \mathrm{~m}$ square could be ignore for the production of the two banana dwarf varieties. Development of dwarf banana cultivar that tolerant to shade is very important, because with the dwarfing banana the population or plant density per unit area will be higher, so that the potential production will be higher also [4].

Mas varieties is a dwarf banana, while Goroho is a dwarf plantain. In Indonesia, Mas is very popular consuming as fresh fruit and for the special use to feed baby, the old as well as for sick person. Goroho is plantain more specific food in Manado City, North Sulawesi Province. The plantain often use as rice substitution especially for diet purpose such a diabetes diet [24]. The starch content of raw plantain up to $60-80 \%$ of its dry weight similar to starch of corn and potato [27]. Goroho has antioxidant activity $13.34 \%$ of the phenol total contain $0.05 \mathrm{mg} / 100 \mathrm{~g}$, vitamin C $69.25 \%$ and tannin $0.13 \%$. The phytosterol and glucoside sterol in goroho flesh is believed that it is could be use as antioxidant [28]. 
Tabel 6. A comparison of the Natural Shade of Coconut Canopy and Open Field for Banana and Plantain Growth and Production

\begin{tabular}{|c|c|c|c|c|c|}
\hline \multirow[t]{2}{*}{ Treatments } & \multicolumn{5}{|c|}{ Banana and plantain varieties } \\
\hline & Mas & Gapi & Gepok & Goroho & Raja \\
\hline $\begin{array}{l}\text { No.ratoon. (3 months): } \\
\text { Under coconut } \\
\text { Open field }\end{array}$ & $\begin{array}{l}5.50 \mathrm{a} \\
5.30 . \mathrm{a}\end{array}$ & $\begin{array}{l}1.32 \mathrm{a} \\
1.30 \mathrm{a}\end{array}$ & $\begin{array}{l}0.23 \mathrm{a} \\
0.25 \mathrm{~b}\end{array}$ & $\begin{array}{l}2.74 \mathrm{a} \\
2.61 \mathrm{~b}\end{array}$ & $\begin{array}{l}1.67 \mathrm{a} \\
1.70 \mathrm{a}\end{array}$ \\
\hline $\begin{array}{l}\text { No.ratoon. (9 months): } \\
\text { Under coconut } \\
\text { Open field }\end{array}$ & $\begin{array}{l}9.30 \mathrm{a} \\
8,95 . \mathrm{a}\end{array}$ & $\begin{array}{l}4.28 \mathrm{a} \\
3.80 \mathrm{~b}\end{array}$ & $\begin{array}{l}4.25 \mathrm{a} \\
5.20 \mathrm{~b}\end{array}$ & $\begin{array}{l}6.53 \mathrm{a} \\
5.43 \mathrm{~b}\end{array}$ & $\begin{array}{l}4.50 \mathrm{a} \\
6.10 \mathrm{~b}\end{array}$ \\
\hline $\begin{array}{l}\text { No.ratoon. }(15 \text { months }) \text { : } \\
\text { Under coconut } \\
\text { Open field }\end{array}$ & $\begin{array}{l}12.50 \mathrm{a} \\
11.97 \mathrm{a}\end{array}$ & $\begin{array}{l}8.47 \mathrm{a} \\
6.98 \mathrm{~b}\end{array}$ & $\begin{array}{l}6.87 \mathrm{a} \\
8.67 \mathrm{~b}\end{array}$ & $\begin{array}{l}8.79 \mathrm{a} \\
7.21 \mathrm{~b}\end{array}$ & $\begin{array}{l}8.00 \mathrm{a} \\
9.10 \mathrm{~b}\end{array}$ \\
\hline $\begin{array}{l}\text { No.ratoon. ( } 21 \text { months): } \\
\text { Under coconut } \\
\text { Open field }\end{array}$ & $\begin{array}{l}15.50 \mathrm{a} \\
16.02 \mathrm{a}\end{array}$ & $\begin{array}{l}10.50 \mathrm{a} \\
8.67 \mathrm{~b}\end{array}$ & $\begin{array}{r}9.75 \mathrm{a} \\
11.03 \mathrm{~b}\end{array}$ & $\begin{array}{l}13.75 \mathrm{a} \\
11.27 \mathrm{~b}\end{array}$ & $\begin{array}{r}9.75 \mathrm{a} \\
11.13 \mathrm{~b} \\
\end{array}$ \\
\hline $\begin{array}{l}\text { No.Leaves ( } 3 \text { months) } \\
\text { Under coconut } \\
\text { Open field }\end{array}$ & $\begin{array}{l}5.22 \mathrm{a} \\
5.30 \mathrm{a}\end{array}$ & 3.57 a 3,37 a & $\begin{array}{l}3.53 \mathrm{a} \\
3.47 \mathrm{a}\end{array}$ & $\begin{array}{l}4.50 \mathrm{a} \\
4.57 \mathrm{a}\end{array}$ & $\begin{array}{l}3.75 \text { a } 5,13 \\
a\end{array}$ \\
\hline $\begin{array}{l}\text { Leaves (6 months) } \\
\text { Under Coconut } \\
\text { Open field }\end{array}$ & $\begin{array}{l}5.75 \mathrm{a} \\
6.08 \mathrm{a} \\
\end{array}$ & $\begin{array}{l}5.28 \mathrm{a} \\
6.27 \mathrm{~b} \\
\end{array}$ & $\begin{array}{l}4.77 \mathrm{a} \\
6.12 \mathrm{~b} \\
\end{array}$ & $\begin{array}{l}6.24 \mathrm{a} \\
6.11 \mathrm{a} \\
\end{array}$ & $\begin{array}{l}5,30 \mathrm{a} \\
6.57 \mathrm{~b} \\
\end{array}$ \\
\hline $\begin{array}{l}\text { No.Leaves (9 months) } \\
\text { Under coconut } \\
\text { Open field }\end{array}$ & $\begin{array}{l}5.76 \mathrm{a} \\
5.82 \mathrm{a}\end{array}$ & $\begin{array}{l}6.76 \mathrm{a} \\
7,80 \mathrm{~b}\end{array}$ & $\begin{array}{l}6.49 \mathrm{a} \\
7.87 \mathrm{~b}\end{array}$ & $\begin{array}{l}6.27 \mathrm{a} \\
6.44 \mathrm{a}\end{array}$ & $\begin{array}{l}5.97 \mathrm{a} \\
7.33 \mathrm{~b}\end{array}$ \\
\hline $\begin{array}{l}\text { Plant height at } \\
\text { inflorescence }(\mathrm{cm}) \\
\text { Under coconut } \\
\text { Open field }\end{array}$ & $\begin{array}{l}181.34 \mathrm{a} \\
16 ., 67 \mathrm{~b}\end{array}$ & $\begin{array}{l}352.65 \mathrm{a} \\
349.67 \mathrm{~b}\end{array}$ & $\begin{array}{l}392.58 \mathrm{a} \\
363.37 \mathrm{~b}\end{array}$ & $\begin{array}{l}223.33 \mathrm{a} \\
200.54 \mathrm{~b}\end{array}$ & $\begin{array}{l}346.83 \mathrm{a} \\
312.17 \mathrm{~b}\end{array}$ \\
\hline $\begin{array}{l}\text { Plant girth at inflorescence } \\
\text { (cm) } \\
\text { Under coconut } \\
\text { Open field } \\
\end{array}$ & \begin{tabular}{|}
$38.45 \mathrm{a}$ \\
$39.22 \mathrm{a}$ \\
\end{tabular} & $\begin{array}{l}60.28 \mathrm{a} \\
62.67 \mathrm{~b} \\
\end{array}$ & $\begin{array}{l}92.40 \mathrm{a} \\
94.56 \mathrm{~b} \\
\end{array}$ & $\begin{array}{l}42.70 \mathrm{a} \\
43.16 \mathrm{a} \\
\end{array}$ & $\begin{array}{l}62.38 \mathrm{a} \\
60.08 \mathrm{~b} \\
\end{array}$ \\
\hline $\begin{array}{l}\text { Days of Flowering } \\
\text { Under coconut } \\
\text { Open field }\end{array}$ & $\begin{array}{l}191.08 \mathrm{a} \\
187.67 \mathrm{a}\end{array}$ & $\begin{array}{l}302,75 \mathrm{a} \\
310.25 \mathrm{a} \\
\end{array}$ & $\begin{array}{l}382,58 \mathrm{a} \\
380.27 \mathrm{a} \\
\end{array}$ & $\begin{array}{l}223.33 \mathrm{a} \\
209.36 \mathrm{a} \\
\end{array}$ & $\begin{array}{l}336.83 \mathrm{a} \\
337.67 \mathrm{a} \\
\end{array}$ \\
\hline $\begin{array}{l}\text { Days of Harvesting } \\
\text { Under coconut } \\
\text { Open field }\end{array}$ & $\begin{array}{l}251.25 \mathrm{a} \\
254.33 \mathrm{a}\end{array}$ & $\begin{array}{l}389.75 \mathrm{a} \\
386.67 \mathrm{a}\end{array}$ & $\begin{array}{l}482.50 \mathrm{a} \\
485.14 \mathrm{a}\end{array}$ & $\begin{array}{l}277.00 \mathrm{a} \\
279.91 \mathrm{a}\end{array}$ & $\begin{array}{l}421.75 \mathrm{a} \\
425.25 \mathrm{a}\end{array}$ \\
\hline $\begin{array}{l}\text { No. Of hand/bunch } \\
\text { Under coconut } \\
\text { Open field }\end{array}$ & $\begin{array}{l}8.25 \mathrm{a} \\
8,23 \mathrm{a}\end{array}$ & $\begin{array}{l}8.27 \mathrm{a} \\
8.23 \mathrm{a}\end{array}$ & $\begin{array}{l}13.50 \mathrm{a} \\
15.45 \mathrm{~b}\end{array}$ & $\begin{array}{l}5.76 \mathrm{a} \\
5.67 \mathrm{a}\end{array}$ & $\begin{array}{l}8.75 \mathrm{a} \\
9.05 \mathrm{a}\end{array}$ \\
\hline $\begin{array}{l}\text { Av. Hand weight (g) } \\
\text { Under coconut } \\
\text { Open field }\end{array}$ & $\begin{array}{l}867.33 \mathrm{a} \\
882.67 \mathrm{a}\end{array}$ & $\begin{array}{l}1496.28 \mathrm{a} \\
1609.67 \mathrm{~b}\end{array}$ & $\begin{array}{l}1778.68 \mathrm{a} \\
1896.33 \mathrm{~b}\end{array}$ & $\begin{array}{l}1224.03 \mathrm{a} \\
1216.89 \mathrm{a}\end{array}$ & $\begin{array}{l}1482.56 \mathrm{a} \\
1602.67 \mathrm{~b}\end{array}$ \\
\hline $\begin{array}{l}\text { No.of fingers/hand } \\
\text { Under coconut } \\
\text { Open field }\end{array}$ & $\begin{array}{l}15.33 \mathrm{a} \\
15.56 \mathrm{a}\end{array}$ & $\begin{array}{l}14.50 \mathrm{a} \\
16.23 \mathrm{~b}\end{array}$ & $\begin{array}{l}17.78 \mathrm{a} \\
18.98 \mathrm{~b}\end{array}$ & $\begin{array}{l}15.33 \mathrm{a} \\
15.02 \mathrm{a}\end{array}$ & $\begin{array}{l}16.13 \mathrm{a} \\
16.27 \mathrm{a}\end{array}$ \\
\hline
\end{tabular}

Notes: Mean followed by the same letter in a column each parameter is not different at $5 \%$ based on $t$ test analysis

\subsection{Tall Varieties}

The three Tall Varieties, Gapi, Gepok Tanjung and Raja tended to show that they were not 
quite suitable cultivated under coconut. Gepok Tanjung, the Tall Plantain, in this experiment is more extreme unsuitable indication. There were not significantly different between planting into natural shade of coconut canopy and open field on parameters: (1) number of leaves measured in 3 months after planting, (2) days of flowering and (3) days of harvesting only. Otherwise, most of the parameters were significantly different, such as: (1) number of ratoon measured in 3 months, (3) number of ratoon measured in 9 months, and (4)number of ratoon measured in 15 months after planting; (5) number of leaves measured in 6 months after planting (6) number of leaves measured in 9 months after planting (7)height in inflorescence, (8) plant girth in inflorescence, (9) Number of hands/bunch, (10) average hand weight, and (11) number of fingers/hand.

Gapi the Tall Banana Variety, was more tolerant toward shade compared with Gepok Tanjung. It has 5 of 14 parameters having indication of tolerance, namely, (1) number of ratoon measured in 3 months after planting, (2) number of leaves measured in 3 months after planting, (3) days of flowering, (4) days of harvesting, and (5) number of hands/bunch. The rest 9 parameters were significantly different between natural shade and open field condition. Then, the other Tall Banana variety, Raja, having better performance under natural shade of coconut canopy with Gepak Tanjung and Gapi varieties. It has 6 of 14 parameters having indication of tolerance, namely, (1) number of ratoon measured in 3 months after planting, (2) number of leaves measured in 3 months after planting, (3) days of flowering, (4) days of harvesting, and (5) number of hands/bunch and (6) number of Number of fingers/hand. The rest 8 parameters were significantly different between natural shade and open field condition. However. The results are still cannot recommend that using the tall varieties as intercrops under coconut based despite of several parameters were not significantly different between shade and open field condition, except any other pattern of spacing of the coconut plantation.

The different responses of dwaft varieties and the tall varieties lead to trial the suitable intercrops into coconut plantation. It it necessary to strive on this due to the important value of the intercropping system. Plantain or banana intercropped are reported to be one of the most profitable coconut intercrops [29]. In addition, plants may interact different in reduced light compared to full sun [30]. Banana and plantain can even grow well in higher shaded level up to $80 \%$. Fruit production will be delayed by several months if plant is excessively shaded. For commercial production of banana, full sun is usually best and a maximum of $50 \%$ shaded is recommended. Reduced irradiance resulted in a significant decrease in fruit production, A reduction to $60 \%$ of full sunlight resulted in a $7 \%$ decrease of bunch weight, and a reduction to $30 \%$ of full sunlight resulted in a decrease of $32 \%$ in bunch weight [31]. Another research correlate to this result, that $50 \%$ shading of full sunlight dose not reduce yield of banana [29].

\section{Conclusion}

There are two dwarf cultivars, Mas (banana) and Goroho (plantain) indicated the significant vegetative and generative growth shorter than the three tall cultivars, Gapi, Gepok Tanjung and Raja. The higher number of ratoon recorded on the Dwarf Mas Cultivar, while the least on the Tall Gepok Tanjung. Meanwhile, the number of leaves were mostly similar among the dwarf and the tall banana and plantain intercropped into the coconut based. The plant height and girth at inflorescence were still different mainly between the dwarf and the tall cultivars. The differences of also reported for generative characters of the dwarf and the tall, such as days of flowering, days of harvesting, number of hands/bunch, number of fingers/hand and average hand weight.

The trials conducted in in Lowland Talawaan Bantik Village, North Sulawesi lead to conclude that coconut based using Hybrid Khina-1 varieties, spacing $8 \mathrm{~m}$ x $8 \mathrm{~m}$ square 
system is suitable for intercropping with banana and plantain, especially the Dwarf Mas (banana) and Goroho (plantain), most parameters of the dwarfs were not different between planting under natural shade of coconut canopy and panting in open field. In the contrary, the tall cultivars, Gapi, Gepok Tanjung and Raja are not recommended. Nevertheless, the talls could be consider to other wider models of coconut spacing, due to the facts that some parameters were not different between planting under natural shade and in open field.

Acknowledgement. The leadership provided by DR. Wahid Rauf and technical assistant by techniciant Demaks Masoara is greatly acknowledged.

\section{References}

1. FAO. FAO Framework on Rural Extreme Poverty. Toword Reaching Targets 1.1 of the Sustainable Development Goals. FAO, Rome (2019)

2. K.R.S.Proud. A guide to Intercropping Coconuts. Upland Farming/ Soil \& Water Conservation Consultant. Prepared for the Upland Development Programme in Southern Mindanao (UDP) (2005)

3. Supadi, A.R. Nurmanaf. Pemberdayaan petani kelapa dalam upaya peningkatan pendapatan petani. Jurnal Penelitian dan Pengembangan Pertanian. Vol.25, No.1, (2006).

4. Muhidin, G.R.Sadimantara, S. Leomo, T.C. Rakian, M.J.Arma1, N.W.S.Suliartini,. The Response of Dwarf Banana Cavendish Growth and Production under Natural Shade. International Journal of ChemTech Research, Vol.9, No.12, pp 541-548 (2016)

5. B.L.Kushwah, E.V. Nelliat, V.T. Markose, A.F.Sunny. Rooting patter $n$ of coconut (Coco s nucifera L.). Indian X Agron. 18: 71-74 (1974)

6. S.H.Pajow, R.B.Maliangkay. Pengaruh tanaman sela jagung terhadap produksi kelapa dan pendapatan petani. Buletin Balitka, 14: 15 (1991)

7. E.V.Nelliat, K.V. Bavappa, P.K.R. Nair. Multistoreyed cropping. A new dimension cropping for coconut plantations. World Crops. 26 (6): 262-266 (1974)

8. S.S.Magat. Light Requirements of Selected Intercrops. Technology Note No. 2. PCAARDB (1999)

9. J.Olivier, E.Andoh-Mensah, R.Arthur, S.K. Dery. Farmers' strategies and replanting performance in the context of coconut lethal yellowing disease along the coastal region in Ghana. CORD 22(1):66- 75 (2006)

10. R.H.Stover, N.W. Simmonds. Bananas (3rd edn). Longman Scientific and Technical, Singapore. p.468 (1987)

11. D.R.Jones. Introduction to banana, abaca and enset. In: Jones DR (ed) Diseases of Banana, Abaca and Enset. CABI Publications, Oxon, United Kingdom, pp 1-36. ISBN 0-85-199-355-9 (2000)

12. J.A.Fortescue, D.W.Turner, R.Romero. Evidence that banana (Musa spp.), a tropical monocotyledon, has a facultative long-day response to photoperiod. Funct Plant Biol 38:867-878 (2011)

13. F.Honfo, K.Hell, O.Coulibaly, A.Tenkouano. Micronutrient value and contribution of plantainderived foods to daily intakes of iron, zinc, and $\beta$-carotene in Southern Nigeria. InfoMusa. The International Journal on Banana and Plantain. Vol.16 No. 1- 2. P.2-6 (2007)

14. S.de Pee, C.E.West. Dietary carotenoids and their role in combating vitamin A 
deficiency. A review of the literature. Europeen Journal of Clinical Nutrition 50 (suppl.): p.38-53 (1996)

15. E. Frossard, J.Chunwongse, S.D. Tanksley. Potential for increasing the content and bioavailability of $\mathrm{Fe}, \mathrm{Zn}$ and $\mathrm{Ca}$ in plants for human nutrition. Journal of the Science of Food and Agriculture 80:861-879 (2000)

16. Q.Meunier, L.Lassois, J.L.Doucet. Guide de plantation et de conduite d'une bananeraie agroforestière en milieu rural au Gabon. DACEFI-2: Développement d'Alternatives Communautaires à l'Exploitation Forestière illégale (seconde phase). P 32 (2011)

17. F.Meutchieye. Fiche Technique de multiplication des bananiers par la méthode de PIF Plants Issus de Fragments de tiges. Manuel de formation pour les communautés rurales. TerrEspoir Cameroun. P.15. (2009).

18. L.Taiz, E.Zeiger. Plant Physiology, 2nd Edition. Sinauer Association, INC., Publishers. Sunderland, Massechussetts, USA (1998).

19. V.P.Bhalerao, A.D.Jagdhani, C.V.Pujari. Effect of different sources of nitrogen on yield and quality of Grand Naine banana. (in):Proceedings of National Conference on Banana, held during 25-28 October at National Research Center for Banana, Thiruchirapalli, p 97.(2007)

20. K.Baruah, B.Sarma, D. Sut. Genetic variability in banana cultivars under Assam conditions. Indian. J. Hort. 64 (3). p 282-285 (2007)

21. M.Rema, K.Aravindakshan, Chandralekha. Evaluation of Plantain (Musa AAB) variability in South India. (in): Abstacts "Global Conference on Banana and Plantain", held during 28-31 October at Bangalore, p 22 Rethinam,P. 2002 (2002)

22. G.Medhi,. Performance of some cultivars of banana (Musa paradisiacal L.) in Assam. Haryana J. Hort. Sci. 23 (3): 181-185 (1994)

23. R.Suhartanto, Sobir, H.Harti. Teknologi Sehat: Budidaya Pisang: Dari Benih Sampai Pasca Panen. Buku Ajar ISBN 978-979-18361-3-5. Pusat Kajian Hortikultura Tropika, LPPM-IPB Kampus IPB Baranangsiang, Jl. Raya Pajajaran Bogor (2012)

24. F.R.T. Suniati, H.Purnomo. Goroho (Musa acuminafe, Sp) banana flou as natural antioxidant source in Indonesian meatball production. Food Research 3 (6): 678-683. Journal homepage:http:/www.myfoodddreseach.com (2019)

25. Takemiya, A.Inouea, S. Doi, M. Kinishita, K.Shimasaki. Phototropins Promote Plant Growth in Response to Blue Light in Low Light Environments. Plant Cell, 17:11201127 (2005)

26. M.de S.Liyanage, H.P.S.Jayasundara, T.G.L.G.Gunasekera. Leucaena as a multipurpose tree for coconut plantations in Sri Lanka, J. Trop. For. Sci. 6: 91- 97 (1992)

27. P.Zhang, R.L.Whistler, J.N.Bemiller, B.R.Hamaker. Banana starch: production, physicochemical properties, and digestibility-a review. Carbohydrate Polymers, 59(4), 443-458 (2005)

28. A.Hardisson, C.Rubio, A.Baez, M.Martin, R.Alvarez, E.Diaz. Mineral composition of the banana (Musa acuminate) from the island of Tenerife. Journal of Food Chemistry, 73(2) (2001)

29. J.G. Ohler. Modern Coconut Managenet; Palm Cultivation and Products. Food and Agriculture Organization of The United Nation. http:/ecoport.org/ep?SearchType= earticleView\&earticled=127\&page $=1383$ (2007)

30. S.N.Azam-Ali, G.R.Squire. Principles of Tropical Agronomy; ISBN 085199136X; p. 236; CABI Publishing Wallingford UK (2002) 
31. Y.Israeli, Z.Plaut, A.Schwartz. Effect of shade on banana morphology, growth and production. Scientia Horticulturae 62:45-56 (1995) 